\title{
EFFECT OF MULCHING AND EMITTER SPACING ON WATER USE EFFICIENCY AND YIELD OF SQUASH
}

\author{
Ahmed M. Hassan* Ehab A. Magdy*
}

\begin{abstract}
Influences of two plastic mulch practices (transparence and black mulching) using trickle irrigation and three emitter spacings (35, 50 and $65 \mathrm{~cm}$ ) on squash yield, soil water availability and WUE were assessed using experimental plots. In comparison to trickle irrigation and conventional surface irrigation, the transparence and black mulching significantly increased squash fruit yield, soil moisture storage (0-60 cm) and WUE. Results indicated that non-mulched treatments (trickle irrigation, DI, at emitter spacings 35, 50 and $65 \mathrm{~cm}$ and surface irrigation, SI, received an average of $328.5 \mathrm{~mm}$ for first three treatments and $698.6 \mathrm{~mm}$ for forth treatment, respectively to produce 21.754, 18.989, 17.336 and 16.054 t/ha squash, respectively, whereas treatments with transparent and black plastic mulching (TMD and BMD) consumed an average of $286.6 \mathrm{~mm}$ and $299.2 \mathrm{~mm}$ water for all emitter spacings (35, 50 and $65 \mathrm{~cm})$, respectively, and yielded average of 33.445, 31.067, 22.816, 33.338, 29.065 and 25.434 t/ha, respectively at same emitter spacings.
\end{abstract}

Keywords: Transparence mulching, black mulching, trickle irrigation, water use efficiency, yield, squash.

\section{INTRODUCTION}

Trigation is an important limiting factor of crop yield, because it is associated with many factors of plant environment, which influence growth and development. Availability of adequate amount of moisture at critical stages of plant growth not only optimizes the metabolic process in plant cells but also increases the effectiveness of the mineral nutrients applied to the crop. Consequently any degree of water stress may produce deleterious effects on growth and yield of the crop (Saif et al., 2003). Surface irrigation method is most widely used all over the world (Mustafa et al., 2003). In Libya squash is generally grown under conventional surface irrigation method.

* Assist. Prof., Ag. Eng. Dept., Faculty of Ag., Cairo Univ. 
In this method, the major proportion of irrigation water is lost by surface evaporation, deep percolation and other loses, resulting in lower irrigation efficiencies. Under limited water supply conditions farmers tend to increase irrigation interval, which creates water stress resulting in low yields and poor quality.

Trickle irrigation is one of the best techniques to use in applying water to vegetables and orchards. It is very popular in water scarcity areas. The system provides more frequent, precise and direct application of water in small quantities in the root zone. Work carried out earlier on trickle irrigation and mulching in fruits and vegetables gave encouraging results in terms of yield and water use efficiency (Raina et al., 1999; Singh et al., 1999). Trickle irrigation, with its ability to provide small and frequent water applications directly in the vicinity of the plant root zone has attracted interest because of decreased water requirement and possible increase in production (Darwish et al., 2003; Janat, 2003). As the world increasingly becomes dependent on the production of irrigated lands, irrigated agriculture faces serious challenges that threaten its suitability. It is prudent to make efficient use of water and bring more area under irrigation through available water resources. This can be achieved by introducing advanced methods of irrigation and improved water management practices (Zaman et al., 2001). Among the water management practices for increasing water use efficiency one of them is mulching. Any material spread on the surface of soil to protect it from solar radiation or evaporation is called mulch. Different types of materials like wheat straw, rice straw, plastic film, grass, wood, sand etc. are used as mulches. They moderate soil temperature and increase water infiltration during intensive rain (Gajri et al., 1994; Khurshid et al., 2006).

A large number of experiments have been conducted to study the effect of drip irrigation and plastic mulch on yield improvement of many crops in different agro-climatic region and soil condition. Squash is also suited to drip irrigation in combination with plastic mulch, but very little work has been done to study the effects of drip irrigation and plastic mulch on crop yield and water use efficiency of squash in semiarid lands of Libya. 
Verma and Acharya, (1996) stated that mulching keep strawberry clean and protect it from its contact with the soil to avoid fruit rot. This practice is also known for moderation of hydrothermal regime and increasing water use efficiency.

Proper field management practices such as mulching and rotation have been suggested to improve crop growth and productivity through enhancing water and nutrient uptake (Mohler and Callaway, 1995; Kouwenhoven et al., 2002). The plastic mulching system has been found to influence soil hydrothermal regime and crop yields (Fisher, 1995; Thiagalingam et al., 1996), which has been widely utilized for a variety of vegetable crops for many years. Although the positive effect of plastic mulch on vegetable crop yield has been reported in many areas (Ells $\boldsymbol{e t}$ al., 1994; Ramalan and Nwokeocha, 2000), the mechanism for its increasing yield remains unclear, and the optimum mulching method has not been well addressed. Plastic mulches directly affect the microclimate around the plant by modifying the radiation budget of the surface and decreasing the soil water loss (Liakatas et al., 1986). Moreover, there are also studies showing plastic mulch has much greater impact on the soil water balance and ultimately improve water use efficiency (WUE) in rain-fed condition (Hatfield et al., 2001; Wang et al., 2004).

The present investigation was planned to determine the effects of drip irrigation, plastic mulch and different emitter spacing on squash yield and water use efficiency (WUE), in addition to their effects on the distribution of water in the soil section.

\section{MATERIALS AND METHODS}

\section{Study area}

The field experiments were carried out during two successive growth seasons of 2012 and 2013, at private farm in Alwaseta (الوسيطة), Elbayda (البيضاء), Libya. The site was located at $449 \mathrm{~m}$ altitude, $32.8^{\circ} \mathrm{N}$ latitude and $21.8^{\circ}$ E longitude.

Some physical soil properties are given in Table 1 . The soil samples were tested in Soil Science Department - Faculty of Agriculture - Cairo University. 
Table (1): Some physical analyses of soil samples.

\begin{tabular}{|c|c|c|c|c|c|c|c|c|}
\hline \multirow[b]{2}{*}{$\begin{array}{c}\text { Depth, } \\
\text { cm }\end{array}$} & \multicolumn{4}{|c|}{ Soil particles distribution } & \multirow[b]{2}{*}{ Soil texture } & \multirow{2}{*}{$\begin{array}{c}\text { Field } \\
\text { capacity, } \\
\%\end{array}$} & \multirow{2}{*}{$\begin{array}{c}\text { Wilting } \\
\text { Point, } \\
\%\end{array}$} & \multirow{2}{*}{$\begin{array}{c}\text { Bulk } \\
\text { density, } \\
\text { g/cm }\end{array}$} \\
\hline & $\begin{array}{c}\text { C. } \\
\text { Sand }\end{array}$ & $\begin{array}{c}\text { F. } \\
\text { Sand }\end{array}$ & Silt & Clay & & & & \\
\hline $\mathbf{0}-\mathbf{2 0}$ & 1.6 & 51.0 & 22.9 & 24 & & 26.4 & 15.3 & 1.40 \\
\hline $20-40$ & 1.7 & 52.2 & 22.4 & 23.7 & Sandy clay loam & 25.5 & 14.2 & 1.41 \\
\hline $40-60$ & 1.7 & 48.6 & 24.4 & 25.3 & Sandy clay loam & 26.8 & 15.1 & 1.39 \\
\hline
\end{tabular}

\section{Planting and agronomic practices}

Squash seed (Cucurbita pepo "F1 Super Jedida") were sown manually in holes at a soil depth of $1.5 \mathrm{~cm}$ on April $20^{\text {th }} 2012$ and $18^{\text {th }}$ April 2013 respectively, on one side of each furrow by keeping row-to-row and plant-to-plant distance $1 \mathrm{~m}$ and $50 \mathrm{~cm}$, respectively.

Fertilizers were applied according to soil test results and Ministry of Agriculture, Libya. Ammonium nitrate was applied at the rate of 203 $\mathrm{kg} / \mathrm{ha}$, Phosphorous at the rate of $35 \mathrm{~kg} / \mathrm{ha}$ and Potassium at the rate of 80 $\mathrm{kg} / \mathrm{ha}$ using injector pump. All other necessary operations such as pest and weed controls were performed according to general local practices and recommendations.

A weather station located in Agriculture Faculty, Omar Elmokhtar University provided hourly temperature, relative humidity, solar radiation and wind speed. The average annual rainfall of $549.1 \mathrm{~mm}$ is concentrated more in the fall and winter than in the summer and spring season. The average temperatures ranged between 9.5 and $23.6{ }^{\circ} \mathrm{C}$, and relative humidity ranged between 59 to $79.3 \%$ and this information was used to calculate reference evapotranspiration (ETo) according to FAO-56 (Allen et al., 1998).

\section{Layout and treatments}

The layout of the experiment was a completely randomized block design with three replicates for each of the four treatments tested, [transparent mulched drip irrigation (TMD), black mulched drip irrigation (BMD), drip irrigation without mulching (DI) and surface irrigation (SI) as controlling treatment] and for each of the three emitter spacing treatments $(35,50$ and $65 \mathrm{~cm})$ as shown in Figure (1).

The experimental area was $780 \mathrm{~m}^{2}$, divided into three blocks. Each block consisted of three plots, $3 \mathrm{~m} \times 20 \mathrm{~m}$ each, in order to control plot 
irrigated with surface irrigation $3 \mathrm{~m} \times 20 \mathrm{~m}$. A border of one meter separated both the blocks and plots. Each plot had three rows, $1 \mathrm{~m}$ apart and $20 \mathrm{~m}$ long, In order to prevent the water in any one plot from affecting its neighboring plots. In both growing seasons, moldboard plow and disk harrow were used for tillage operations. The irrigation was carried out by a drip system of emitters (4 1/h) spaced 35, 50 and $65 \mathrm{~cm}$ apart, by each plant, on $16 \mathrm{~mm}$ (ID) laterals, one per row of squash. Each plot had a PE manifold pipeline of $50 \mathrm{~mm}$ diameter. The irrigation water, which was pumped from a deep well, was conveyed by means of PE pipes of $63 \mathrm{~mm}$ diameter to the manifolds along the border of the plots. The self-compensating emitters operate at a pressure of $100 \mathrm{KPa}$. The used plastic mulch was black polyethylene $(40 \mu \mathrm{m})$ for (BMD), and clear transparent polyethylene $(100 \mu \mathrm{m})$ for (TMD).

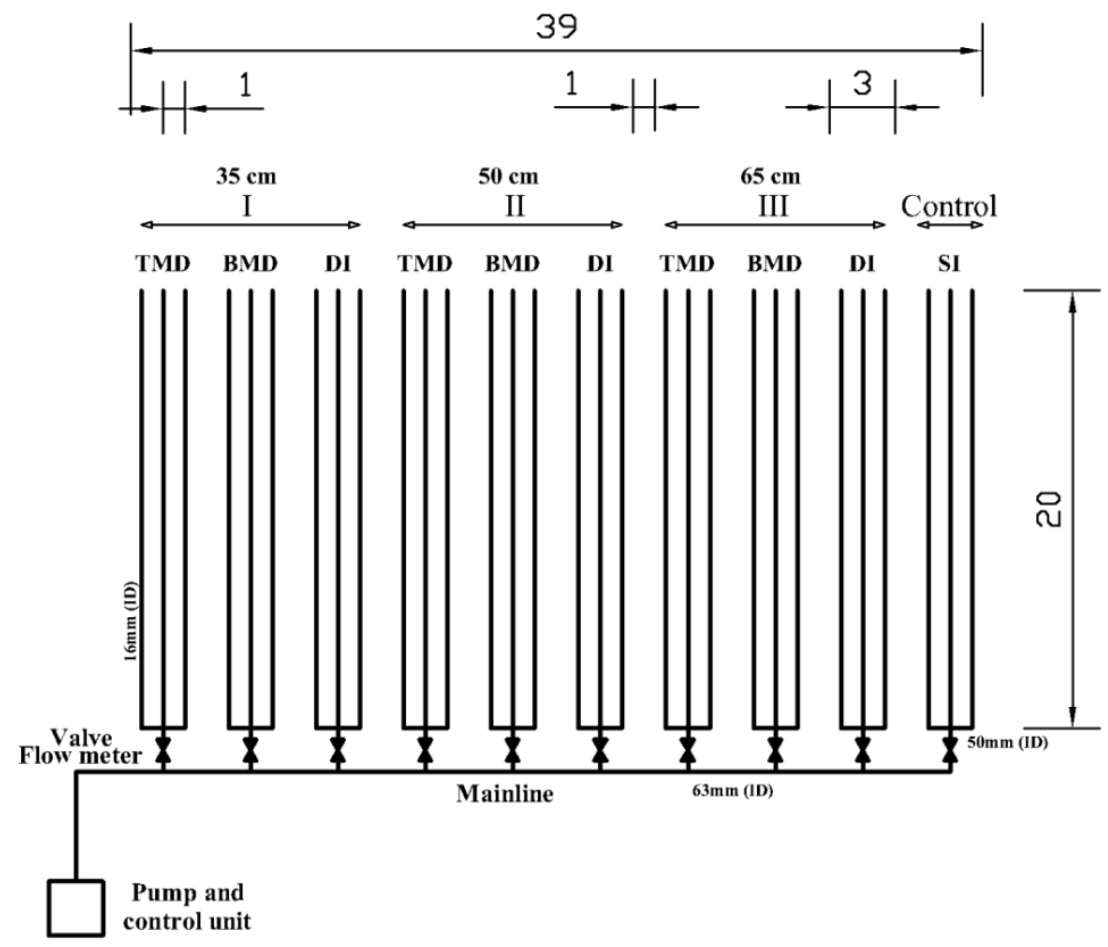

Figure (1): Layout of squash experiment and irrigation system.

\section{Measurements}

Mercury soil thermometers were installed at the surface of soil, at the 5 $\mathrm{cm}$ soil depth and at the $10 \mathrm{~cm}$ soil depth in each treatment, i.e., a total of 
30 thermometers. Temperature was recorded from planting date till the end of the season. Measurements were taken each three hours of the day twice a week.

Ambient air temperature was taken from a nearby weather station. The yield (t/ha) from each plot was recorded in each pick, and the effectiveness of squash in using water during its complete growth period is generally described in terms of WUE $\left(\mathrm{kg} / \mathrm{m}^{3}\right)$ and is expressed as the ratio of total crop yield $(\mathrm{kg} / \mathrm{ha})$ to the total water applied to crop $\left(\mathrm{m}^{3} / \mathrm{ha}\right)$ including effective rainfall during its complete growth period (Lovelli et al., 2007).

Tensiometers were installed near the center of each plot between two plants and distanced 10, 20, 30, 40 and $50 \mathrm{~cm}$ from irrigation line. Soil moisture tension readings were taken at $20 \mathrm{~cm}$ depth intervals before and after each irrigation. SURFER 9 software was used to graph the readings after obtaining the calibration curve. Irrigation scheduling was based on the calibrated tensiometer readings, whereas irrigation was applied at 75 $\%$ of field capacity according to the effective roots distribution zone.

Gross water requirement $\left(\mathrm{IR}_{\mathrm{g}}\right)$ for each plot was controlled by the special valve set for that plot, and the exact amounts used were read on a flow meter $\left(0.0001 \mathrm{~m}^{3}\right.$ accuracy). The net irrigation requirement $\left(\mathrm{IR}_{\mathrm{n}}\right)$ must replenish the actual crop evapotranspiration water $\left(\mathrm{ET}_{\mathrm{a}}\right)$, as rainfall and other components of the water balance. The gross irrigation requirements $\left(\mathrm{IR}_{\mathrm{g}}\right)$ must increase the $\left(\mathrm{IR}_{\mathrm{n}}\right)$, in order to compensate the irrigation efficiency and to leach salts:

$$
I R_{g}=\frac{I R_{n}}{E_{a}(1-L R)}
$$

Where $\mathrm{E}_{\mathrm{a}}(\%)$ : irrigation efficiency coefficient and LR: minimum amount of leaching needed to control salts with drip irrigation which equals to zero in study region.

ETa (mm/day) was estimated using the following form of the water balance equation (Simonne and Dukes, 2010):

$$
\mathrm{ET}_{\mathrm{a}}=\frac{\sum \mathrm{D}\left(\theta_{\mathrm{vi}}-\theta_{\mathrm{vf}}\right)}{\text { days }}
$$

Where $\left(\Theta_{\mathrm{vi}}-\Theta_{\mathrm{vf}}\right)$ : is the change in volumetric soil water content between two measurement dates, D (mm): is the thickness of soil layer.

Reference crop evapotranspiration (ETo) was estimated using the CROPWAT software based on FAO Penman-Monteith method (Allen et 
al., 1998). The crop coefficient, $\mathrm{K}_{\mathrm{c}}$ for squash was basically determined by the ratio of the crop $\mathrm{ET}_{\mathrm{c}}$ to the reference $\mathrm{ET}_{\mathrm{o}}$, whereas: $\mathrm{K}_{\mathrm{c}}=\mathrm{ET}_{\mathrm{c}} / \mathrm{ET}_{\mathrm{o}}$ (FAO, 1998).

\section{Statistical analysis}

Data on squash yield and water use efficiency (WUE) were statistically analyzed. Analysis of variance (ANOVA) was performed using two-way ANOVA from MSTAT software. All the treatment means were compared for any significant differences using the Duncan's multiple range tests at significant level of $\mathrm{P}_{0.05}$.

\section{Water applied}

\section{RESULTS AND DISCUSSION}

Before planting, $9.5 \mathrm{~cm}$ irrigation water was applied to all treatments to bring the soil water content in $0-60 \mathrm{~cm}$ soil depth up to level of field capacity. Irrigation schedule was started measuring of soil water tension by tensiometers. The amount of water applied to the squash was 698.6 $\mathrm{mm}$ in the SI treatment, $328.5 \mathrm{~mm}$ in the DI treatment, $286.6 \mathrm{~mm}$ in the TMD treatment and $299.2 \mathrm{~mm}$ in the BMD treatment as average during both of growing seasons as shown in Table (2). It was noted that the number of irrigations $(\mathrm{N}=18)$ in the TMD treatments almost similar to BMD $(\mathrm{N}=19)$ treatments, while this parameter was in non-mulched treatments $(\mathrm{N}=15)$ in SI treatments and $(\mathrm{N}=23)$ in DI treatment. These results are also in agreement with those of Ertek et al. (2006) and Zotarelli et al. (2009). Non-mulched treatment (DI) reduces irrigation intervals compared with mulched treatments TMD and BMD as shown in Table (2), and attributed to the large ranges of soil moisture of the rooting zone.

\section{Water movement in the soil}

The irrigation water was applied to compensate the water deficiency of the root zone soil $(60 \mathrm{~cm})$, according to (Allen et al., 1998) for squash effective roots distribution zone. Monitoring the soil water content in the trickle irrigated plots revealed that infiltration below $60 \mathrm{~cm}$ depths was negligible especially in mulched plots compared with that of nonmulched plots as shown in Figure 2.

The readings indicate that plastic mulching has a pronounced effect on trickle irrigation effectiveness through the good estimation of wetting bulb's dimensions under the emitter and understanding its moisture changes in place and time, whereas the use of trickle irrigation with 
plastic mulch reduced both of evaporation from soil surface and water distribution area in the soil away from the lines of irrigation, which has extreme effect on irrigation water distribution pattern, root distribution, efficiency of the fertilizers, water use and ultimately on the squash production, these results are also in agreement with those of Pawar et al. (2002) and Yaghi et al. (2013).

The results showed that the highest application efficiency was recorded with transparent plastic mulch and black polyethylene mulch compared to DI as shown in Table (2).

Table (2): Net irrigation requirements, $I_{\mathrm{n}}(\mathrm{mm})$; gross irrigation requirements, $I_{\mathrm{g}}(\mathrm{mm})$, number of irrigations, $\mathrm{N}$, and irrigation efficiency, $E_{a}$, for the study treatments, as an average during months of the both of growing seasons (2012 and 2013).

\begin{tabular}{|c|c|c|c|c|c|c|c|c|c|c|c|c|}
\hline Treat. & \multicolumn{3}{|c|}{ TMD } & \multicolumn{3}{|c|}{ BMD } & \multicolumn{3}{|c|}{ DI } & \multicolumn{3}{|c|}{ SI } \\
\hline Month & $\mathbf{N}$ & $\mathbf{I R}_{\mathrm{n}}$ & $\mathbf{I R}_{\mathrm{g}}$ & $\mathbf{N}$ & $\mathbf{I R}_{\mathrm{n}}$ & $\mathbf{I R}_{\mathrm{g}}$ & $\mathbf{N}$ & $\mathbf{I R}_{\mathrm{n}}$ & $\mathbf{I R}_{\mathrm{g}}$ & $\mathbf{N}$ & $\mathbf{I R}_{\mathrm{n}}$ & $\mathbf{I R}_{\mathrm{g}}$ \\
\hline April & $\mathrm{N}=\mathbf{2}$ & $\begin{array}{l}5.2 \\
6.6\end{array}$ & $\begin{array}{l}5.3 \\
6.9\end{array}$ & $\mathrm{~N}=\mathbf{2}$ & $\begin{array}{l}5.3 \\
6.7\end{array}$ & $\begin{array}{l}5.6 \\
7.1\end{array}$ & $\mathbf{N}=\mathbf{3}$ & $\begin{array}{l}5.1 \\
3.7 \\
5.8\end{array}$ & $\begin{array}{l}5.3 \\
4.1 \\
6.3\end{array}$ & $\mathbf{N}=\mathbf{3}$ & $\begin{array}{l}13.4 \\
16.7 \\
19.4\end{array}$ & $\begin{array}{l}21.3 \\
26.9 \\
31.7\end{array}$ \\
\hline May & $N=5$ & $\begin{array}{l}10.8 \\
11.6 \\
12.1 \\
16.1 \\
21.3\end{array}$ & $\begin{array}{l}11.3 \\
12.1 \\
13.7 \\
17.8 \\
22.6\end{array}$ & $N=6$ & $\begin{array}{c}8.3 \\
8.8 \\
9.7 \\
12.1 \\
14.1 \\
18.6\end{array}$ & $\begin{array}{c}8.9 \\
9.4 \\
10.4 \\
13.0 \\
15.2 \\
20.2\end{array}$ & $N=10$ & $\begin{array}{c}5.1 \\
5.5 \\
5.6 \\
6.8 \\
7.1 \\
8.5 \\
9.3 \\
10.1 \\
11.2 \\
11.3\end{array}$ & $\begin{array}{c}5.8 \\
6.1 \\
6.2 \\
7.8 \\
7.8 \\
9.7 \\
10.7 \\
11.2 \\
12.1 \\
12.1\end{array}$ & $N=4$ & $\begin{array}{l}22.9 \\
27.5 \\
29.7 \\
33.7\end{array}$ & $\begin{array}{l}37.7 \\
45.2 \\
48.1 \\
55.3\end{array}$ \\
\hline June & $N=6$ & $\begin{array}{l}19.4 \\
18.6 \\
19.9 \\
19.7 \\
19.8\end{array}$ & $\begin{array}{l}21.5 \\
20.3 \\
21.4 \\
21.1 \\
21.2\end{array}$ & $N=6$ & $\begin{array}{l}18.8 \\
17.7 \\
17.7 \\
18.3 \\
18.5 \\
18.6\end{array}$ & $\begin{array}{l}20.4 \\
19.2 \\
19.3 \\
19.7 \\
20.1 \\
20.3\end{array}$ & $N=11$ & $\begin{array}{c}9.3 \\
9.1 \\
9.8 \\
11.6 \\
11.3 \\
11.3 \\
11.7 \\
11.9 \\
12.0 \\
11.9\end{array}$ & $\begin{array}{l}10.0 \\
10.3 \\
10.4 \\
12.4 \\
12.4 \\
12.9 \\
12.9 \\
13.2 \\
13.2 \\
13.3\end{array}$ & $N=4$ & $\begin{array}{l}34.9 \\
32.3 \\
33.2 \\
34.1\end{array}$ & $\begin{array}{l}57.4 \\
\mathbf{5 2 . 9} \\
\mathbf{5 4 . 7} \\
\mathbf{5 6 . 3}\end{array}$ \\
\hline July & $N=5$ & $\begin{array}{l}21.4 \\
21.2 \\
21.0 \\
22.5\end{array}$ & $\begin{array}{l}22.1 \\
22.7 \\
22.5 \\
24.1\end{array}$ & $N=5$ & $\begin{array}{l}22.3 \\
22.1 \\
16.9 \\
21.6\end{array}$ & $\begin{array}{l}24.3 \\
23.8 \\
18.4 \\
23.9\end{array}$ & $\mathbf{N}=9$ & \begin{tabular}{c|}
12.8 \\
13.1 \\
12.5 \\
11.6 \\
10.6 \\
7.3 \\
9.0 \\
10.3 \\
5.1
\end{tabular} & $\begin{array}{c}14.3 \\
14.3 \\
14.1 \\
13.1 \\
12.1 \\
8.1 \\
9.6 \\
11.1 \\
5.6\end{array}$ & $N=4$ & $\begin{array}{l}34.4 \\
33.7 \\
31.2 \\
28.6\end{array}$ & $\begin{array}{l}56.7 \\
55.6 \\
51.5 \\
47.3\end{array}$ \\
\hline Total & $N=18$ & 267.1 & 286.6 & $N=19$ & 276.2 & 299.2 & $N=23$ & 297.3 & 328.5 & $N=15$ & 425.7 & 698.6 \\
\hline $\mathbf{E}_{a}, \%$ & & 93.2 & & & 92.3 & & & 90.5 & & & 60.9 & \\
\hline
\end{tabular}


Generally, all mulches increased of soil moisture and water use efficiency. Therefore, the different types of mulch lead to increasing the soil moisture due to decreased of evaporation from soil surface compared to open field treatment. So, mulches finding favorable soil environmental conditions and had a positive effect on growth of squash plants and contributed to increasing vegetative growth and yield.

Similar results were reported by Yaghi et al. (2013). Table (2) and Figure (2) can help to derive that applied trickle irrigation effectiveness for TMD, BMD and DI was 93.2, 92.3 and $90.5 \%$ while it decreases to 60.9 $\%$ for SI. The percent of water use reduction was $59 \%, 57.1 \%$ and $53 \%$ for TMD, BMD and DI, respectively, compared with SI.

\section{Squash production and water use efficiency (WUE)}

The present study shows the effects of drip irrigation and plastic mulch on crop water requirement and WUE. The results indicated that TMD treatment markedly decreased the amounts of applied water in the order $\mathrm{TMD}<\mathrm{BMD}<\mathrm{DI}<\mathrm{SI}$ and increased WUE in the order TMD $>\mathrm{BMD}>$ DI $>$ SI. The highest WUE $\left(11.7 \mathrm{~kg} / \mathrm{m}^{3}\right)$ was obtained for the $\mathrm{TMD}_{35}$ treatment because this treatment consumed about $59 \%$ and $12.8 \%$ less water than the SI and DI treatments respectively, and produced comparatively higher yield. The lowest WUE $\left(2.3 \mathrm{~kg} / \mathrm{m}^{3}\right)$ realized for the SI treatment can be ascribed to the fact that the $144 \%$ more water was applied to this treatment than the TMD treatments, while yield of the SI method was $48 \%$ of the $\mathrm{TMD}_{35}$ treatment. These results are also in agreement with those of Kirnak and Demirtas (2006), Ngouajio et al. (2006) and Seyfi and Rashidi (2007). Results indicated that nonmulched treatments $\left(\mathrm{DI}_{35}, \mathrm{DI}_{50}, \mathrm{DI}_{65}\right.$ and $\left.\mathrm{SI}\right)$ received an average of $328.5 \mathrm{~mm}$ for first three treatments and $698.6 \mathrm{~mm}$ for forth treatment, respectively to produce $21.754,18.989,17.336$ and $16.054 \mathrm{t} /$ ha squash, respectively, whereas treatments with transparent and black plastic mulching (TMD and BMD) consumed an average of $286.6 \mathrm{~mm}$ and $299.2 \mathrm{~mm}$ water for all emitter spacings, respectively and yielded average of 33.445, 31.067, 22.816, 33.338, 29.065 and 25.434 t/ha. These results support those of Wien et al. (1993), who showed that increased tomato growth and yield by polyethylene mulching is a consequence of enhanced root growth and nutrient uptake early in the season. 

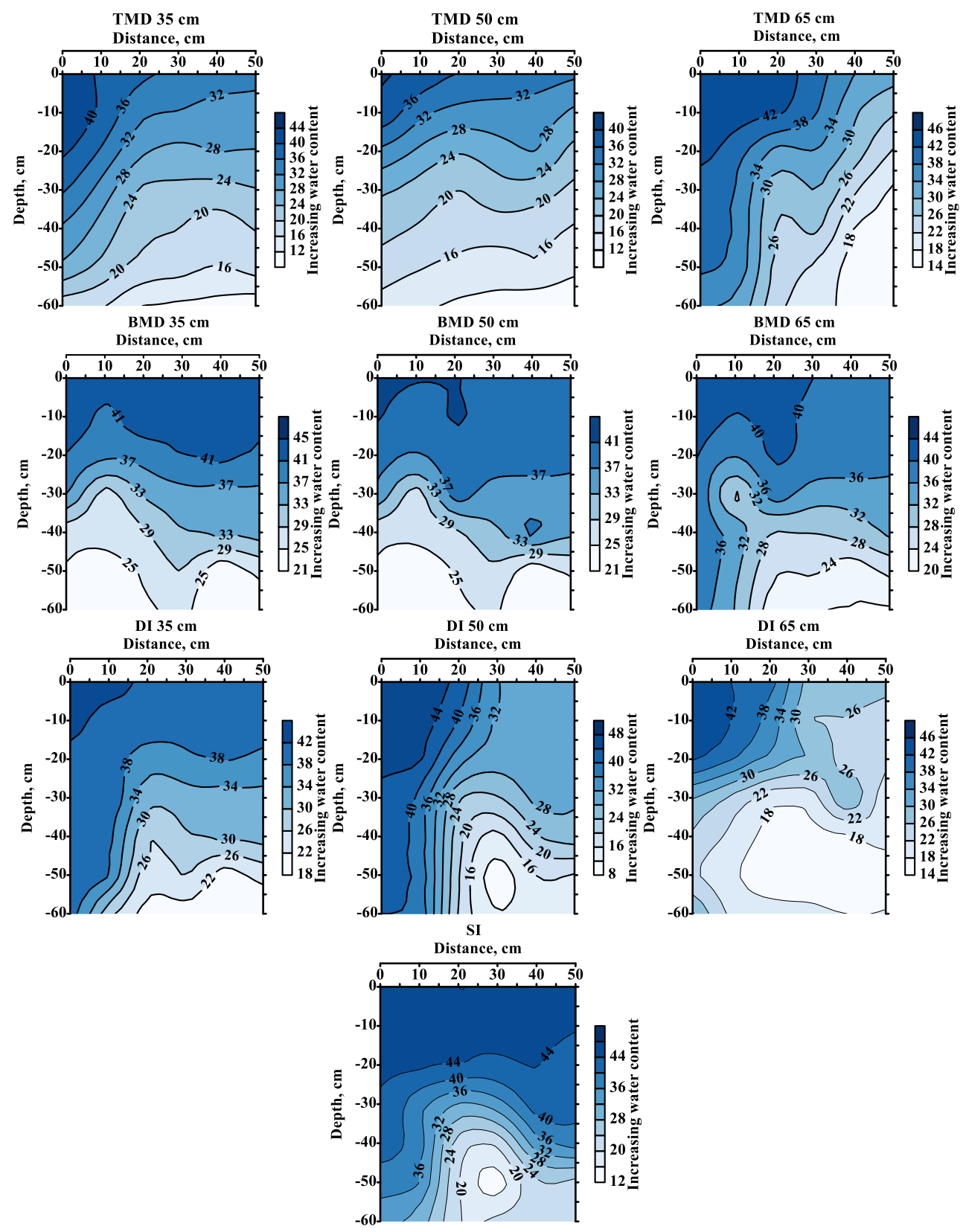

Figure (2): Diagrams of water content in soil after irrigation for different treatments and emitters spacing (average two seasons 2012 and 2013).

Statistical analyses using the F-test were carried out. As shown in Table (3), the results showed significant differences in yield and WUE between treatments at 0.05 level, whereas transparent mulch with drip irrigation 
exceeded all the treatments of the study in the order TMD $>$ BMD $>$ DI $>$ SI.

Table (3): Water applied, yield and water use efficiency (WUE) of different treatments (mean of 2012 and 2013).

\begin{tabular}{|c|c|c|c|c|c|c|c|c|c|c|c|}
\hline \multirow{3}{*}{ Parameters } & \multicolumn{9}{|c|}{ Treatments } & \multirow{3}{*}{ SI } & \multirow{3}{*}{$\begin{array}{l}F \\
\text { test }\end{array}$} \\
\hline & & TMD & & & BMD & & & DI & & & \\
\hline & $35 \mathrm{~cm}$ & $50 \mathrm{~cm}$ & $65 \mathrm{~cm}$ & $35 \mathrm{~cm}$ & $50 \mathrm{~cm}$ & $65 \mathrm{~cm}$ & $35 \mathrm{~cm}$ & $50 \mathrm{~cm}$ & $65 \mathrm{~cm}$ & & \\
\hline Water applied (mm) & 286.6 & 286.6 & 286.6 & 299.2 & 299.2 & 299.2 & 328.5 & 328.5 & 328.5 & 698.6 & \\
\hline Yield (t/ha) & 33.445 & 31.076 & 22.816 & 33.338 & 29.065 & 25.434 & 21.754 & 18.969 & 17.336 & 16.054 & * \\
\hline WUE $\left(\mathrm{kg} / \mathbf{m}^{3}\right)$ & 11.7 & 10.8 & 8 & 11.1 & 9.7 & 8.5 & 6.6 & 5.8 & 5.3 & 2.3 & * \\
\hline
\end{tabular}

* The significant difference at 5\% level.

Plastic mulches raise soil temperature in the planting bed which promotes faster crop development and earlier yields. Whereas germination dates for TMD, BMD, DI and SI were on April 25, 25, 27 and 28, respectively, maturity dates were on May 30, 31, 3 and 5 at the same previous arrangement. Also it is associated with the best vegetative growth and significantly increased productivity limits of (108\%, $108 \%$ and $36 \%)$ for TMD, BMD and DI at emitter spacing $35 \mathrm{~cm}$ compared with the SI treatment. Increased yield could be largely attributed to the increase in soil temperature due to application of plastic mulch which resulted in an enhancement of soil environment around roots of squash plants, which led to increasing plant growth and, hence, increasing nutrients uptake. Hence, earlier production and higher total yield was obtained. The results reported that the greatest total yield of squash plants was obtained with transparent polyethylene mulch followed by black polyethylene and then by drip irrigation without mulching.

\section{Actual crop evapotranspiration, ET}

$\mathrm{ET}_{\mathrm{c}}(\mathrm{mm})$ for each treatment was calculated during various squash growth stages. It is noted that DI and SI consumed more water (328.5, $698.6 \mathrm{~mm}$, respeqtively) than BMD or TMD, which had similar values, as shown in Table (2). It is also explained that trickle irrigation system with plastic mulches (black and transparent) substantially prevent the evaporation from the soil surface. Associated with the reduction in evaporation is a general increase in transpiration from squash leaves caused by the transfer of both sensible and radiative heat from the surface of the plastic cover to adjacent vegetative leaves. Evaporation increased especially during the first weeks after transplanting where plants did not 
have enough canopies to shade the soil. Plastic mulches directly affect the microclimate around the plant by modifying the radiation budget (absorptivity vs. reflectivity) of the surface and decreasing the soil water loss.

Table (4): Average monthly solar radiation, minimum and maximum temperature, rainfall, wind, reference evapotranspiration (ET) during both of experimental seasons (mean of 2012 and 2013).

\begin{tabular}{|c|c|c|c|c|c|c|c|}
\hline Month & $\begin{array}{l}\text { Temp } \\
\text { Max. }\end{array}$ & $\begin{array}{l}\text { ature } \\
\text { Min. }\end{array}$ & $\begin{array}{c}\text { Rainfall, } \\
(\mathrm{mm})\end{array}$ & $\begin{array}{c}\text { Relative } \\
\text { humidity, \% }\end{array}$ & $\begin{array}{c}\text { Sunshine, } \\
\text { h }\end{array}$ & $\begin{array}{c}\text { Wind speed, } \\
(\mathrm{m} / \mathrm{s})\end{array}$ & $\begin{array}{l}\mathbf{E T}_{\mathbf{o}}{ }^{*}, \\
(\mathbf{m m})\end{array}$ \\
\hline April & 19.7 & 10.2 & 21.9 & 75.4 & 8 & 3.1 & 101.1 \\
\hline May & 24.0 & 13.6 & 9 & 59 & 10 & 3.8 & 164.6 \\
\hline June & 27.2 & 16.6 & 0 & 58.9 & 12 & 4.2 & 192.0 \\
\hline July & 28.1 & 18.8 & 0 & 61.3 & 12 & 4.6 & 204.9 \\
\hline
\end{tabular}

* From FAO Penman-Monteith method

Table (4) shows the climatic data as average during both of experimental seasons.

Reference crop evapotranspiration ( $\mathrm{ET}_{\mathrm{o}}$ ) values were calculated based on FAO Penman-Monteith method. It was noted that $\left(\mathrm{ET}_{\mathrm{o}}\right)$ values reached the maximum value during July. Also crop evapotranspiration $\left(\mathrm{ET}_{\mathrm{c}}\right)$ started to increase from the date of sowing till midseason stage and reached maximum in July and then declined again at the end of mid and late season stages in the last of July as shown in Table (5).

Table (5): Actual evapotranspiration $\operatorname{ET}_{\mathbf{c}}(\mathrm{mm})$, and length of squash growth stages, $\mathrm{Lg}_{\mathrm{g}}$ (days), as average in the both of growing seasons (mean of 2012 and 2013).

\begin{tabular}{|c|c|c|c|c|c|c|c|c|c|c|c|c|}
\hline \multirow{2}{*}{ Stage } & \multicolumn{3}{|c|}{ TMD } & \multicolumn{3}{|c|}{ BMD } & \multicolumn{3}{|c|}{ DI } & \multicolumn{3}{|c|}{ SI } \\
\hline & $\mathbf{E T}_{\mathbf{0}}$ & $\mathbf{E T}_{\mathrm{c}}$ & $\mathbf{L g}_{\mathrm{g}}$ & $\mathbf{E T}_{\mathbf{0}}$ & $\mathbf{E T}_{\mathrm{c}}$ & $\mathbf{L}_{\mathrm{g}}$ & $\mathbf{E T}_{\mathbf{0}}$ & $\mathbf{E T}_{\mathbf{c}}$ & $\mathbf{L}_{\mathrm{g}}$ & $\mathbf{E T}_{\mathbf{0}}$ & $\mathbf{E T}_{\mathbf{c}}$ & $\mathbf{L}_{\mathrm{g}}$ \\
\hline Init. (Lini) & 13.5 & 3.1 & 4 & 20.2 & 5.3 & 6 & 37.1 & 12.4 & 11 & 47.7 & 44.3 & 13 \\
\hline Dev. $\left(\mathbf{L}_{\text {dev }}\right)$ & 113.9 & 31.6 & 24 & 123.1 & 38.4 & 25 & 138.1 & 52.9 & 26 & 116.8 & 108.4 & 22 \\
\hline Mid. (L $\left.L_{\text {mid }}\right)$ & 339 & 149.1 & 55 & 323.1 & 152.1 & 52 & 284.7 & 151.3 & 45 & 289.3 & 299.4 & 47 \\
\hline Late. (Llate) & 72.7 & 30.3 & 11 & 72.7 & 32.2 & 11 & 79.3 & 39.6 & 12 & 79.3 & 59.3 & 12 \\
\hline Total & 539.1 & 213.9 & 94 & 539.1 & 228 & 94 & 539.1 & 256.2 & 94 & 539.1 & 511.4 & 94 \\
\hline
\end{tabular}

\section{Crop coefficient}

The crop coefficient $\left(\mathrm{K}_{\mathrm{c}}\right)$ values decreased by an average of $\leqslant \vee, 0 \%$ due to use drip irrigation with plastic mulch which reduced soil evaporation compared with non-mulched treatments (SI and DI), as shown in Figure 3. Also when compare $\mathrm{K}_{\mathrm{c}}$ given in Allen et al. (1998) with squash crop coefficient values it noted that the $\mathrm{K}_{\mathrm{c}}$ values closer to ones which were calculated in SI treatment. 


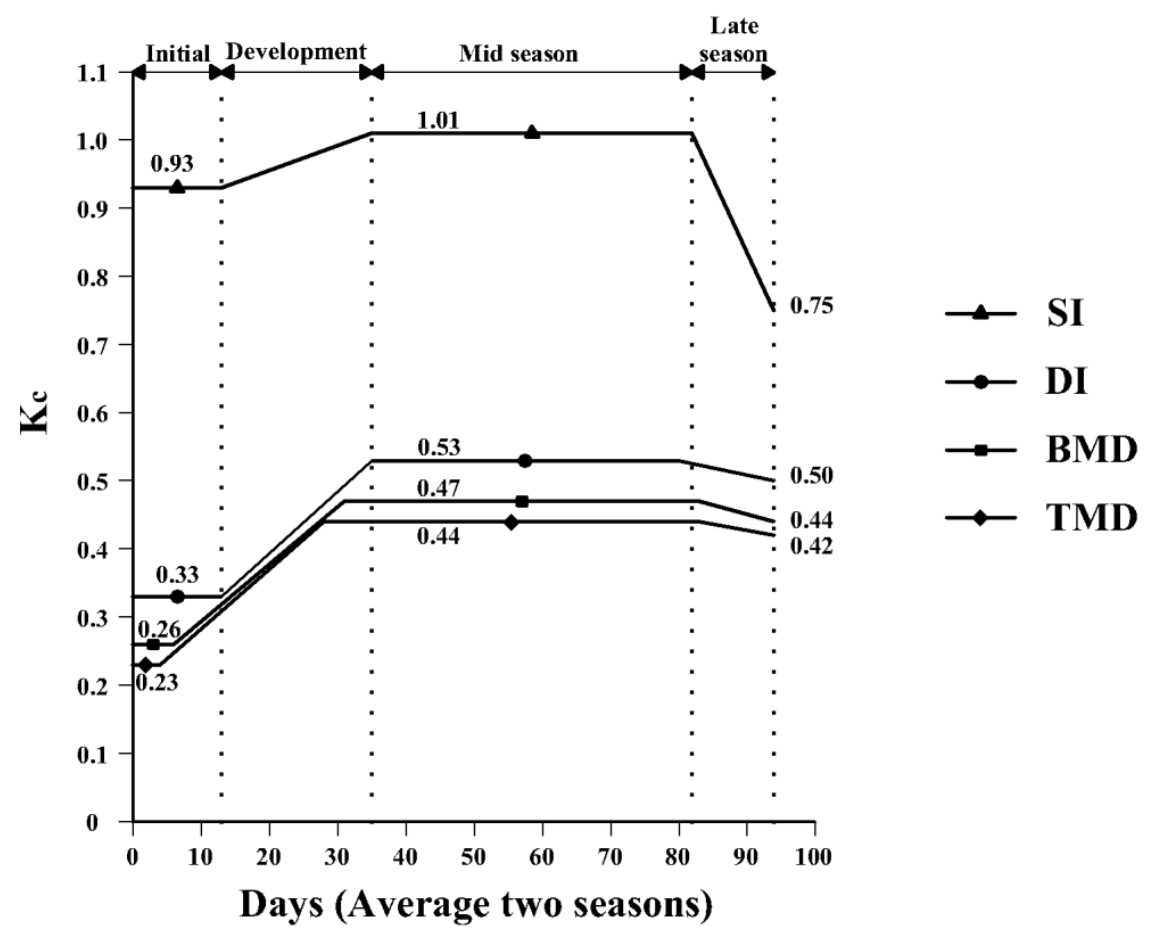

\section{Soil temperature}

Figure (3): Squash crop coefficient curves.

Soil temperature was measured at soil surface and two depths 5 and 10 $\mathrm{cm}$, every 3 hours, respectively during day, twice a week. The results are presented as average during both of seasons as shown in Figure (4).

Average air temperatures were generally higher than soil temperatures which measured at depths of un-mulched treatments. It reached a minimum during of the third quarter of April of $10.2{ }^{\circ} \mathrm{C}$ at 6 a.m. It increased to a maximum of $18.6{ }^{\circ} \mathrm{C}$ in the morning and $33{ }^{\circ} \mathrm{C}$ in the afternoon in July. Air temperatures remained higher than soil temperatures at all depths in previous treatments except in both of TMD and BMD treatments. The values of soil temperature with mulching are much higher than those of soil without mulching. This may be owing to mulching prevents cooling of the soil surface due to evaporation. The values of soil temperature under transparent mulch were higher than those under the black mulch. These transparent plastic mulch may permit warming of (as an average during day) (7.6, 7.4 and $\left.5.8^{\circ} \mathrm{C}\right),(6.9,7.1$ and $\left.5.7{ }^{\circ} \mathrm{C}\right)$ and $\left(6.9,7.2\right.$ and $\left.5.6{ }^{\circ} \mathrm{C}\right)$ to a depths of 0,5 and $10 \mathrm{~cm}$ for emitter 
spacing 35, 50 and $65 \mathrm{~cm}$, respectively, whereas black plastics permit warming of $\left(3,4.6\right.$ and $\left.3.8^{\circ} \mathrm{C}\right),\left(2.7,4.4\right.$ and $\left.3.7{ }^{\circ} \mathrm{C}\right)$ and $(2.7,4.4$ and 3.6 $\left.{ }^{\circ} \mathrm{C}\right)$ at the same previous depths and emitter spacings compared to the treatments without mulching.

\section{Emitter spacing $35 \mathrm{~cm}$}

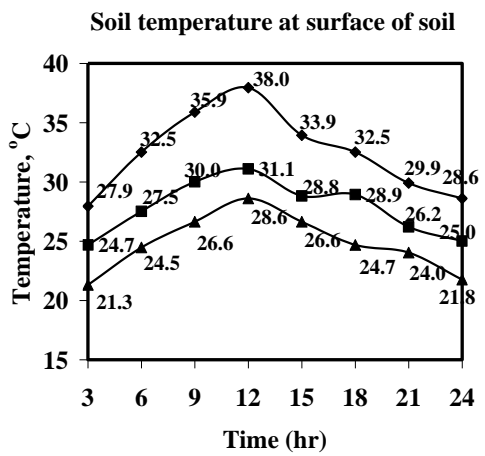

Soil temperature at soil depth $5 \mathrm{~cm}$

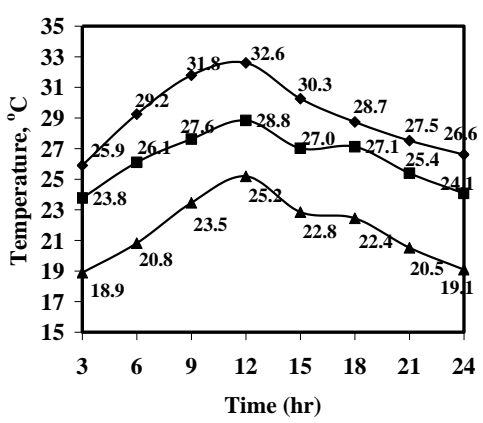

Soil temperature at soil depth $10 \mathrm{~cm}$

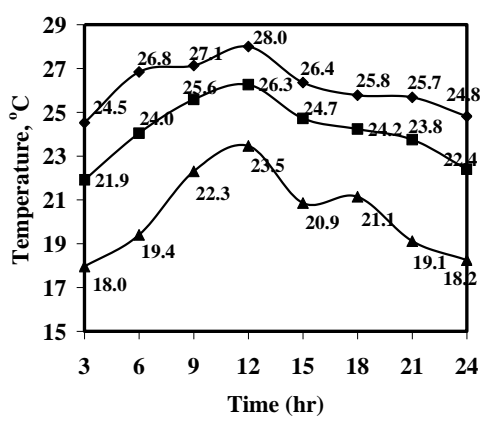

Emitter spacing $50 \mathrm{~cm}$

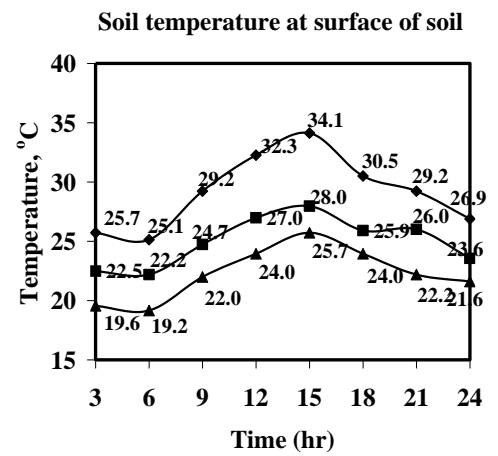

Soil temperature at soil depth $5 \mathrm{~cm}$

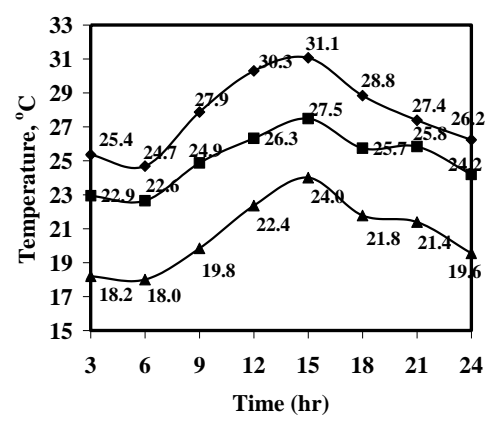

Soil temperature at soil depth $10 \mathrm{~cm}$

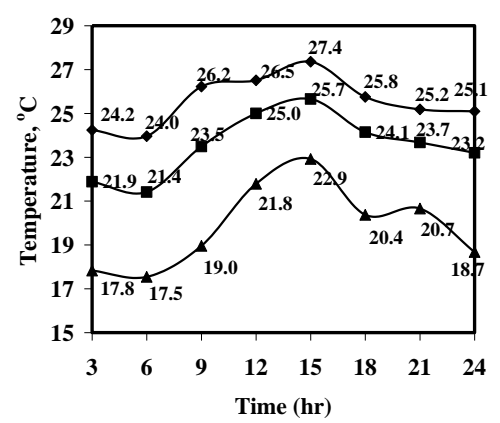

\section{Emitter spacing $65 \mathrm{~cm}$}

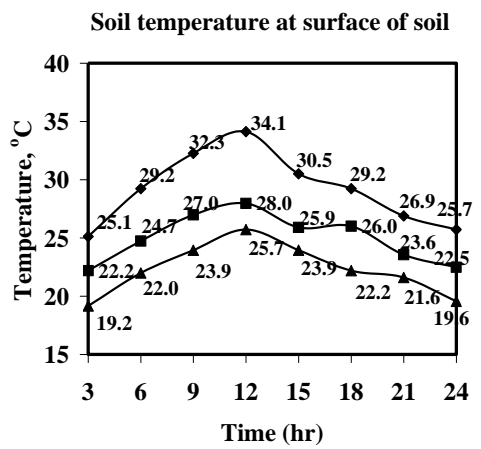

Soil temperature at soil depth $5 \mathrm{~cm}$

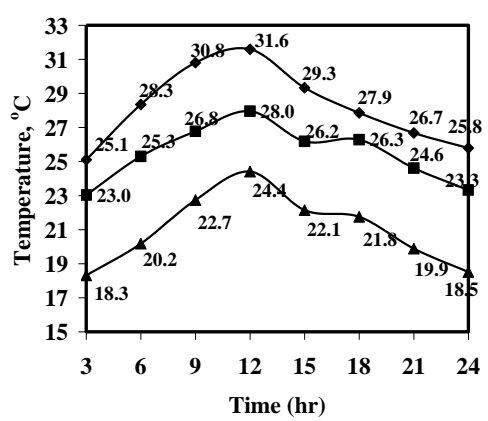

Soil temperature at soil depth $10 \mathrm{~cm}$

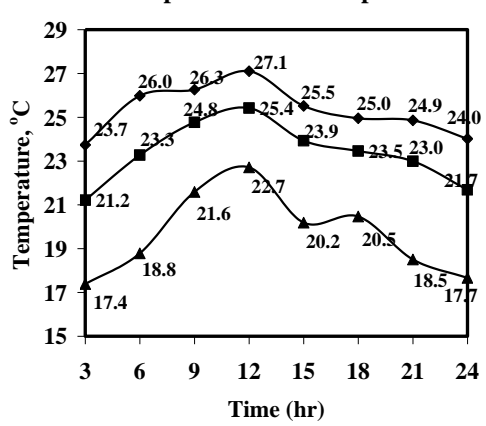

$\rightarrow$ TMD $\rightarrow$ BMD $\leftarrow$ Unmulshed

Figure (4): Average of soil temperature along the growing two seasons under mulched and un-mulched squash at the surface of soil and two depths 5 and $10 \mathrm{~cm}$ and three emitter spacings 35, 50 and 65 cm (mean of 2012 and 2013). 
Using mulch types (transparent and black) enhanced soil temperature. Transparent plastic mulch increased soil temperature more than black mulch especially during the first weeks after transplanting where plants did not have enough canopies to shade the soil. The degree on contact between the mulch and soil, often quantified as a thermal contact resistance, can affect greatly the performance of mulch. If an air space is created between the plastic mulch and the soil by a rough soil surface, soil warming can be less effective than would be expected from particular mulch.

Sunlight passes through the transparent plastic and heats the soil. A layer of water underneath the plastic retains the radiant heat at night through what is known as a greenhouse effect. Black plastic mulch absorbs most of the sunlight and becomes greatly warmed, and little energy passes through to warm the soil.

These results support those of Lamont (2005) and Ngouajio and Ernest (2005) who showed that transparent mulch absorbs only $5 \%$ of shortwave radiation, reflects only $11 \%$, but transmits $84 \%$ of short-wave radiation, whereas surface temperatures do not reach the levels found on black plastic due to their low absorption rates of short-wave radiation. That means that transparent plastics actually heat the soil by transmitting light to the soil surface rather than conducting heat like dark plastics. While differently Liakatas et al. (1986) and Ham et al. (1993) explained that laying transparent mulch loosely across the soil creates an insulating air gap between the mulch and soil that results in higher daytime temperatures under transparent plastic than black plastic mulch. Then, if clear plastic is laid tightly across the bed, its effects will be minimized and, in this situation, black plastic laid tightly across the bed would be more effective at heating the soil.

\section{CONCLUSION}

The objective of this work is to study the effects of drip irrigation, plastic mulch and different emitter spacing on squash yield and irrigation water use efficiency (WUE), in addition to their effects on the distribution of water in the soil profile. 


\section{The following conclusion can be made:}

- The amount of water applied to the squash was $698.6 \mathrm{~mm}$ in the SI treatment, $328.5 \mathrm{~mm}$ in the DI treatment, $286.6 \mathrm{~mm}$ in the TMD treatment and $299.2 \mathrm{~mm}$ in the BMD treatment as average of two growing seasons.

- The number of irrigations $(\mathrm{N}=18)$ in the TMD treatments almost similar to BMD $(\mathrm{N}=19)$ treatments, while was in non-mulched treatments $(\mathrm{N}=15)$ in SI treatments and $(\mathrm{N}=23)$ in DI treatment.

- The use of trickle irrigation with plastic mulch reduced both of evaporation from soil surface and water distribution area in the soil away from the lines of irrigation.

- Non-mulched treatment (DI) reduces irrigation intervals compared with mulched treatments TMD and BMD, and attributed to the large ranges of soil moisture of the rooting zone.

- The highest soil moisture values were recorded with transparent plastic mulch and black polyethylene mulch compared to DI.

- The applied trickle irrigation efficiency for TMD, BMD and DI was $93.2,92.3$ and $90.5 \%$ while it decreases to $60.9 \%$ for SI. The percent of water use reduction was $59 \%, 57.1 \%$ and $53 \%$ for TMD, BMD and DI, respectively, compared with SI.

- The highest WUE $\left(11.7 \mathrm{~kg} / \mathrm{m}^{3}\right)$ was obtained with the $\mathrm{TMD}_{35}$ treatment, while the lowest WUE was $\left(2.3 \mathrm{~kg} / \mathrm{m}^{3}\right)$ recorded with the SI treatment.

- The non-mulched treatments $\mathrm{DI}_{35}, \mathrm{DI}_{50}, \mathrm{DI}_{65}$ and SI produced $21.754,18.989,17.336$ and 16.054 t/ha squash, respectively, while $\mathrm{TMD}_{35}, \mathrm{TMD}_{50}, \mathrm{TMD}_{65}, \mathrm{BMD}_{35}, \mathrm{BMD}_{50}$ and $\mathrm{BMD}_{65}$ treatments yielded an average of 33.445, 31.067, 22.816, 33.338, 29.065 and $25.434 \mathrm{t} / \mathrm{ha}$, respectively.

- The crop coefficient $\left(\mathrm{K}_{\mathrm{c}}\right)$ values decreased by an average of 47.5 $\%$ due to use drip irrigation with plastic mulch which reduced soil evaporation compared with non-mulched treatments (SI and DI).

- TMD treatment permit warming relative to DI treatment of (as an average during day) $\left(7.6,7.4\right.$ and $\left.5.8{ }^{\circ} \mathrm{C}\right),\left(6.9,7.1\right.$ and $\left.5.7{ }^{\circ} \mathrm{C}\right)$ and (6.9, 7.2 and $\left.5.6{ }^{\circ} \mathrm{C}\right)$ to a depths of 0,5 and $10 \mathrm{~cm}$ for emitter spacing 35, 50 and $65 \mathrm{~cm}$, respectively, whereas BMD treatment 
permit warming of $\left(3,4.6\right.$ and $\left.3.8{ }^{\circ} \mathrm{C}\right),\left(2.7,4.4\right.$ and $\left.3.7{ }^{\circ} \mathrm{C}\right)$ and $\left(2.7,4.4\right.$ and $\left.3.6{ }^{\circ} \mathrm{C}\right)$ at the same previous depths and emitter spacings compared to the treatments without mulching (DI and SI).

\section{REFERENCES}

Allen, R.G.; L.S. Pereira; D. Raes and M. Smith. 1998. Crop evapotranspiration. Guidelines for computing crop water requirements. FAO I. and Drain. Paper No. 56, FAO, Rome, Italy, 300.

Darwish, T.; T. Atallah; M. Hajhasan and S. Chranek. 2003. Management of nitrogen by fertigation of potato in Lebanon. Nutrient Cycling in Agroecosystems 67, 1-11.

Ells, J.E.; A. E. McSay; E. G. Kruse and G. Larson. 1994. Root distribution and proliferation of field grown acorn squash as influenced by plastic mulch and water. Hort. Technol . 4, 248-252.

Ertek, A., S. Sensoy; I. Gedik and K. C. Küc, ükyumuk. 2006. Irrigation scheduling based cucumber (Cucumis sativus L.) grown under field condition. Agricultural Water Management 81 (1-2), 159-172.

Farias-Larios, J.; S. Guzman and A. C. Michel. 1994. Effect of plastic mulches on the growth and yield of cucumber in a tropical region. Biological Agriculture and Horticulture 10 (4), 303-306.

FAO 2010. Food and Agriculture Organization of the United Nations. http://www.faostat.fao.org. 16Aug. 2012.

Fisher, P.D. 1995. An al ternative plastic mulching system for improved water management in dry land maize production. Agric. Water Manage. 27, 155-166.

Gajri, P.R.; V. K. Arora and M. R. Chaudhary. 1994. Maize growth, response to deep tillage, straw mulching and farmyard manure in coarse textured soils of N.W. India. Soil Use and Management 10, 15-20. 
Ham, J.M.; G. J. Kluitenberg and W. J. Lamont. 1993. Optical properties of plastic mulches affect the field temperature regime. Journal of American Society of Horticultural Sciences 228 (2), 188-193.

Hatfield, J. L.; T. J. Sauer and J. T. Prueger. 2001. Managing soils to achieve greater water use efficiency: a review. Agron. J. 93, 271280.

Janat, M. 2003. Effect of drip fertigation on improvement of potato yield and water use efficiency. In: AECS -A/RRE, 126., pp. 1-38.

Khurshid, K.; M. Iqbal; M. S. Arif and A. Nawaz. 2006. Effect of tillage and mulch on soil physical properties and growth of maize. International Journal of Agriculture and Biology (5), 593-596.

Kirnak, H. and N. M. Demirtas. 2006. Effect of different mulches on yield and macronutrition levels of drip - irrigation cucumber via open field conditions. Journal of Plant Nutrition 29 (9), 1675-1690.

Kouwenhoven, J.K.; U. D. Perdok, J. Boer and G. J. M. Oomen. 2002. Soil management byshallow mouldboard ploughing in the Netherlands. Soil Till. Res. 65, 125-139.

Lamont, W.J. 2005. Plastics: modifying the microclimate for the production of vegetable crops. HortTechnology 15, 477-481.

Liakatas, A.; J. A. Clark and J. L. Monteith. 1986. Measurements of the heat balance under plastic mulches. Part I. Radiation balance and soil heat flux. Agriculture for Meteorology 36, 227-239.

Lovelli, S.; M. Perniola; A. Ferrara and T. Di Tommaso. 2007. Yield response factor to water (Ky) and water use efficiency of Carthamus tinctorius L. and Solanum melongena L. Agric. Water Manage. 92, 73-80

Mohler, C. H. L. and M. B. Callaway. 1995. Effects of tillage and mulch on weed seedproduction and seed banks in sweet corn. J. Appl. Ecol. 32, 627-639. 
Mustafa, O. S.; I. M. Arshad and S. A. Sattar. 2003. Adoption of kostiakof model to determine the soil infiltration for surface irrigation methods under local conditions. International Journal of Agriculture and Biology 1, 40-42.

Ngouajio, M. and J. Ernest. 2005. Changes in the physical, optical, and thermal properties of polyethylene mulches during double cropping. Hortscience 40, 94-97.

Ngouajio, M.; G. Wanga and R. Goldy. 2006. With holding of drip irrigation between transplanting and flowering increases the yield of field-grown tomato under plastic mulch. Agricultural Water Management 87 (3), 285-291, Available at: Science Direct.

Raina, J. N.; B. C. Thakur; M. L. Verma. 1999. Effect of drip irrigation and polyethylene mulch on yield, quality and water-use efficiency of tomato. Indian J. Agric. Sci. 60 (6), 430-433.

Ramalan, A. A. and C. U. Nwokeocha. 2000. Effects of furrow irrigation methods,mulching and soil water suction on the growth, yield and water use efficiency of tomato in the Nigerian Savanna. Agric. Water Manage. 45 (3),317-330.

Oweis, D. 2012. On-farm Water Management: from efficiency to productivity. In: Training Course on Improving Water Productivity in Agricultural Systems, Amman, Jordan (NCARE) May 6th to May 24th, IWLMP-ICARDA.

Pawar, D. D.; P. G. Bhoi and S. H. Shinde. 2002. Effect of irrigation methods and fertilizer levels on yield of potato (Solanum tuberosum). Indian Journal of Agricultural Sciences 72 (2), 80-83.

Saif, U.; M. Maqsood; M. Farooq; S. Hussain and A. Habib. 2003. Effect of planting patterns and different irrigation levels on yield and yield component of maize (Zea mays, L.). International Journal of Agriculture and Biology 1, 64-66.

Seyfi, K. and M. Rashidi. 2007. Effect of drip irrigation and plastic mulch on crop yield and yield components of Cantaloupe. International Journal of Agriculture and Biology 9 (2), 247-249. 
Simonne, E.H. and M. D. Dukes 2010. Principles and Practices of Irrigation Management for Vegetables. UF, University of Florida, Horticulture Science Dept, IFAS Extension, pp. 17-23.

Singh, S.; A. Singh; V. P. Singh; S. Singh and A. Singh. 1999. Use of dust mulch and antitransparent for improving water use efficiency of menthol mint. J. Med. Aromat. Plant Sci. 21 (1), 29-33.

Steyn, J.M.; H.F. Plessis; P. Fourier; and T. Roos. 2000. Irrigation scheduling of drip irrigated potatoes. In: Proceeding of 6th International Micro-irrigation Congress, Micro-irrigation Technology for Developing Agriculture, South Africa, 22-27 October.

Thiagalingam, K.; N. P. Dalgliesh; N. S. Gould; R. L. M cCown; A. L. Cogle and A. L. Chapman, , 1996. Comparison of no-till and conventional tillage in the developmentof sustainable farming systems in the semi-arid tropics. Aust. J. Exp. Agric. 36,995-1002.

Verma, M. L. and C. L. Acharya. 1996. Waster stress indices of wheat in relation to soil water conservation practices and nitrogen. J. Indian Soc. Soil Sci. 44 (3), 368-375.

Weber, C. 2000. Biodegradable foil mulch for pickling cucumbers. Gemuse Munchen 36 (4), 30-32.

Wien, H. C.; P. L. Minotti and V. P. Grubinger. 1993. Polyethylene mulch stimulates early root growth and nutrient uptake of transplanted tomatoes. Journal of the American Society for Horticultural Science 118 (2), 207-211.

Yaghi, T.; A. Arstan and F. Naoum. 2013. Cucumber (Cucumis sativus, L.) water use efficiency (WUE) under plastic mulch and drip irrigation. Agricultural Water Management 128: 149- 157.

Zaman, W.U.; M. Arshad and A. Saleem. 2001. Distribution of nitrate nitrogen in the soil profile under different irrigation methods. International Journal of Agriculture and Biology 2, 208-209.

Zotarelli, L.; J.M. Scholberg; M.D.Dukes; R. Munoz-Carpena and J. Icerman. 2009. Tomato yield, biomass accumulation, root 
distribution and irrigation water use efficiency on a sandy soil, as affected by nitrogen rat and irrigation scheduling. Agricultural Water Management 96 (1), 23-34.

\section{الملخص العربي}

تأثير الأغطية البلاستيكية والمسافة بين النقاطات على كفاعة الاستخدام المائي وانتاجية الكوسة بنة

\section{أحمد محروس حسن" ايهاب عبد المنعم مجدي"*}

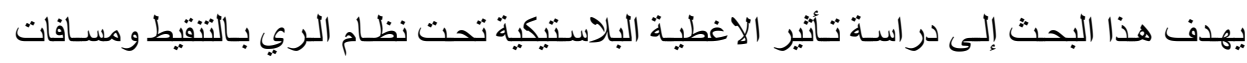

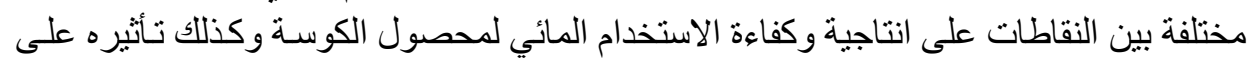
توزيع المياه في قطاع التربة.

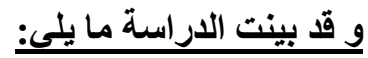

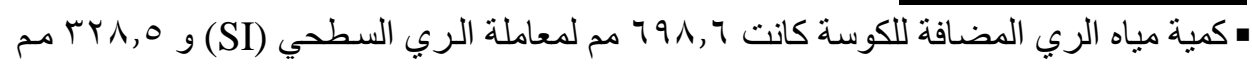

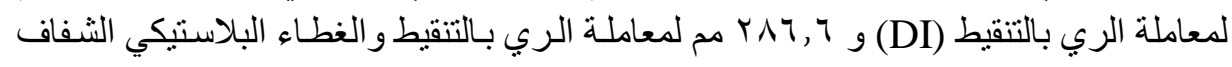

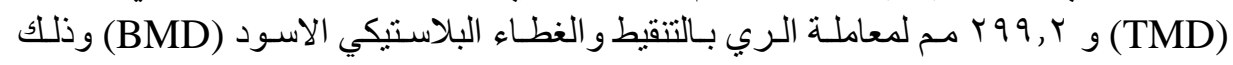
لجميع المسافات بين النقاطات.

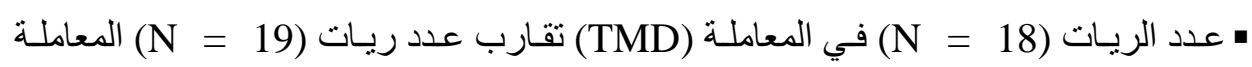

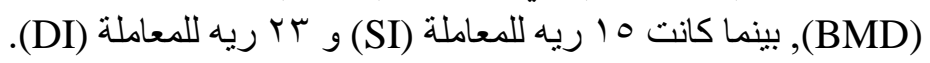

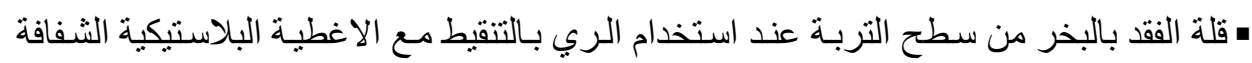

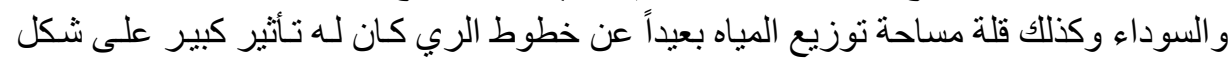

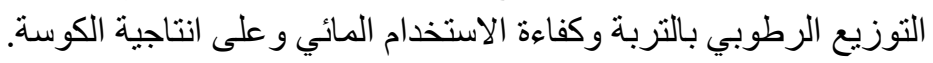

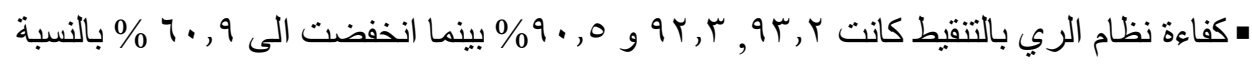

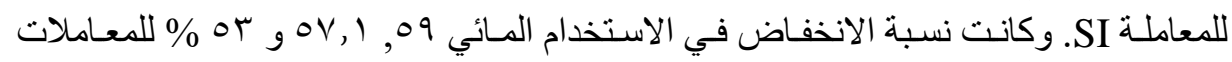

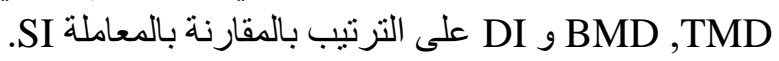

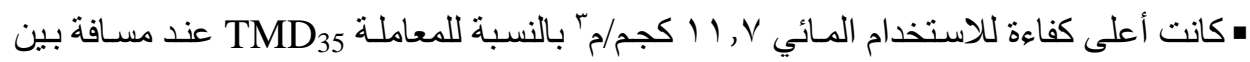

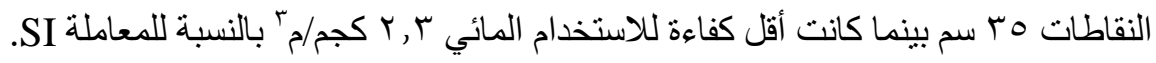

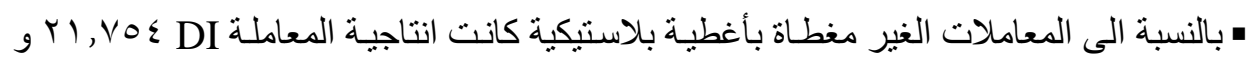

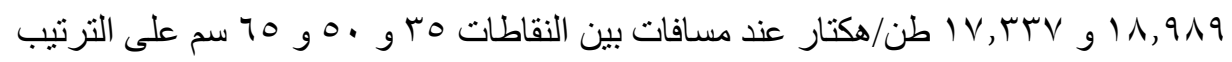

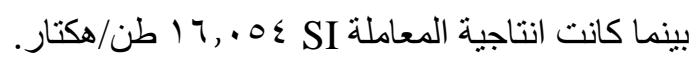

*مدرس بقسم الهندسة الزراعية ـ كلية الزراعة - جامعة القاهرة - ومعار حالياً بجامعة عمر

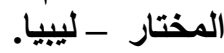
* * مدرس بقَّم الهندسة الزراعية ـ كلية الزراعة - جامعة القاهرة. 
• بالنسبة الى المعاملات المغطاة بالأغطية البلاستيكية كانت انتاجية المعاملة

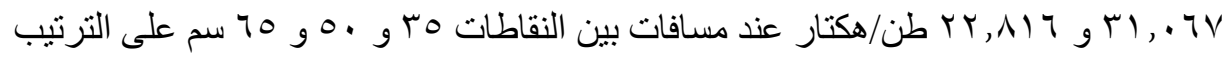

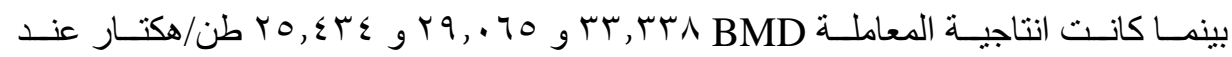
مسافات بين النقاطات هب و ، .0 و 70 سم على الترتيب.

ه نقصت قيم معامل المحصول (Kc) بنسبة 47.5 \% نتيجـة استخدام الري بـالتنقيط مع الآغطيـة

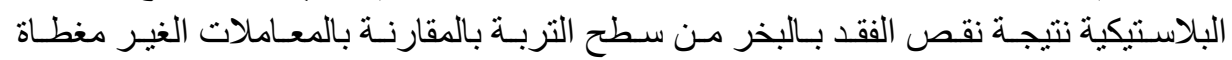
بالأغطية البلاستيكية.

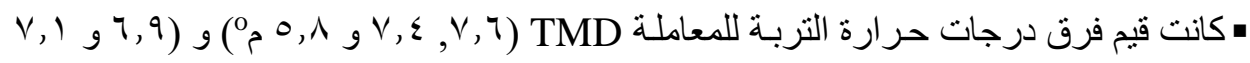

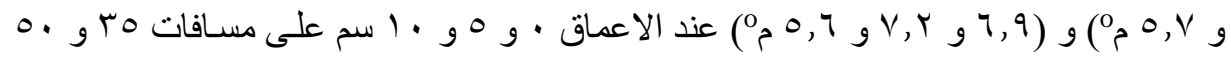

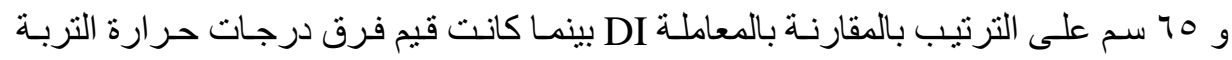

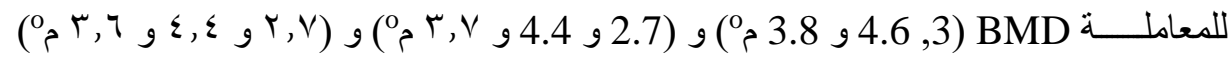

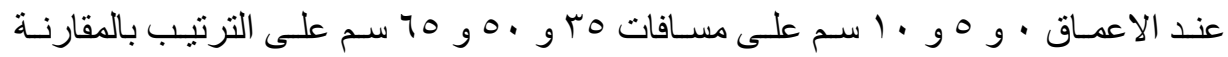

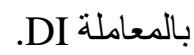

